\title{
The dominance of apprenticeships in the German VET system and its implications for Europeanisation: a comparative view in the context of the EQF and the European LLL strategy
}

\author{
Thomas Deissinger*, Robin Heine and Mariska Ott \\ University of Konstanz, Konstanz, Germany
}

\begin{abstract}
Germany's apprenticeship system is and has always been considered to be the major sub-system of VET. In this context, the debate circling around the European and German Qualifications Framework (EQF and DQR) has become one of the central issues of VET research and policy. Tasks take on a concrete shape if (a) a serious approach is adopted towards the ideas underlying the European Qualifications Framework; and (b) if consideration is given to the 'construction sites' typical for the German VET system as a whole. This paper intends to sharpen VET policy awareness for the problem of dealing with those unresolved German VET issues within the context of the development of the DQR. A comparative view includes Austria and France as two countries with diverging learning cultures in VET from the German case, but obviously with more 'European' imprints within their respective VET systems. It can be shown that there is an interrelation between the attention apprenticeships as such receive against the background of European ideas such as 'progression', 'permeability' and 'lifelong learning' (LLL), including the implementation and use of 'hybrid qualifications'.
\end{abstract}

Keywords: apprenticeship; dual system; European Qualifications Framework; permeability; hybrid qualifications; Germany; Austria; France; VET reform

Introduction: diversification and hybridity as 'European' issues against the background of Germany's VET tradition and the challenges of the EQF

VET traditions and 'learning cultures' as challenges of European VET policy

In a 'system' perspective, VET can take different shapes. Besides apprenticeships, school-based patterns of vocational learning, such as 'vocational grammar schools' in France, 'vocational colleges' in Germany or further education colleges in the UK, represent more or less traditional features which are normally institution-based, shaped by state influence and more or less clearly didactically steered pedagogical arrangements. There are, however, differences when it comes to formally linking up these traditional structures with general or higher education. It also seems that countries differ in terms of their respective VET traditions and 'learning cultures', especially when it comes to the relationship between sub-systems, such as full-time VET and companybased training, but also with respect to Europe, in terms of the adaptability of VET systems to overarching European VET policy ideas and concepts.

*Corresponding author. Email: Thomas.Deissinger@uni-konstanz.de 
The latter are clearly visible if one picks up the notion of National Qualifications Frameworks, supporting 'the objectives of strong and accessible qualifications pathways, a transparent qualifications system, and one that facilitates lifelong learning' (Keating 2008, 1). The European Union - with the implementation of the European Qualifications Framework (EQF) - sees the boundaries between various sectors of the educational and/or training system, including higher and further education, as more and more permeable sub-systems. This premise is based on a specific understanding of 'competence' - very similar to the concepts developed in Anglo-Saxon countries, such as Australia and the UK with rather 'open' training markets where strong formal regulation is absent (Harris 2001; Misko 1999). It is obvious that this openness affects those educational sub-systems most that are strongly tradition-based, clearly functional and more or less independent from other sectors within the education system. The idea of a flexible, individual and ongoing acquisition of competences which should be independent from 'input factors' corresponds with open learning arrangements that are no longer linked to specific courses, curricula, training times or examinations.

The issue of permeability also raises the question about structural links between the different educational sub-systems. Especially the permeability between vocational and general education has emerged as a major focus of European education and training policies and one of the objectives of the EQF. Permeability and progression in this context mean that vocational qualifications should also bear an educational value as such and should, both formally and informally, enable graduates to proceed to higher education. Some countries in Europe, including the UK, but also France, Austria and Switzerland, have developed structures of 'hybridity', although this does not necessarily mean that the political intention to establish a more diversified and multi-functional VET system coincides with the traditional pattern of VET in the various countries. Hereby, 'hybrid qualifications' have a 'hub function' as they should prepare for qualified entrance into working life (in the sense of VET) while at the same time opening access to higher education. ${ }^{1}$

\section{European VET policy issues from a German perspective}

In this context, which includes new approaches to assessment (Wolf 1995; Deissinger and Hellwig 2005; Hellwig 2006) such as RPL (recognition of prior learning) or APL (accreditation of prior learning), four issues may be identified as especially relevant for a tradition-based VET system such as the German one, where apprenticeships have been the long-standing successful mode of integrating young people into skilled employment. Nevertheless, spin-off activities are currently on the way for establishing a German Qualifications Framework (Deutscher Qualifikationsrahmen or DQR), the first draft of which was published in February 2009. With it came a number of issues onto the educational agenda which have a strong 'innovative' though at the same time 'controversial' character:

- The first issue refers to the transfer of an European understanding of competence determining the $\mathrm{EQF}$ to a national semantic level, i.e., the task to come to terms with the specific German tradition and use of 'competence', which can be described as 'holistic' rather than 'functional' (Delamare Le Deist and Winterton 2005), and the construction of a 'competence matrix' featuring vertical differentiation in reference levels and horizontal differentiation with respect to various competence dimensions. 
- The second issue refers to the description of the matrix units which result from the eight levels and three competence dimensions (knowledge, skills, competences) making up the basic structure of the EQF, while the German framework has now been presented with four competence dimensions (technical competence, methodical competence, social competence, personal competence).

- The third issue or step is to establish existing 'qualifications' (certificates) within the draft DQR matrix. This means that qualifications (which are normally strongly input-steered as they are based on training times, curricula, examination modes, etc) have to be translated into notions of competence which have to be aligned with the various levels of the DQR.

- The fourth issue certainly is the most demanding one: competences that are not normally bundled as qualifications have, in a strong European understanding, to be linked with the levels and range of matrix units that make up the NQF. This issue, however, only seems solvable once the unique positioning of existing qualifications is being questioned and/or relations are being established between the 'regular' and the 'irregular' system of entitlements (including, of course, further training and, above all, the field of informal and non-formal learning).

At the moment, it is above all the fourth step, at least in the case of Germany, which seems to be lying in the future, although this aspect certainly possesses a strong political dimension. Besides these and interrelated political and technical issues, there is no doubt that the process of establishing a consensus-borne $\mathrm{DQR}$ in the end requires a common understanding and a common will of stakeholders to tackle the 'building sites' of the German VET system. This means that the structural tasks directly affecting the $\mathrm{DQR}$ are just one step which needs to be taken. Moreover, Germany is also facing the issue of legal, administrative and political consequences arising with the competence matrix which in the end needs to be filled 'with life' in educational policy terms.

\section{The dominance of the 'dual system' in German VET}

The German discussion may be illustrated by referring to those arguments put forward by the representatives of trade unions and the craft sector, which both line up in defending the so-called 'dual system' (duales System) of apprenticeship training as the 'heart' of the German VET system (Greinert 1994). The papers by Esser (2009) and Nehls (2008), as representatives of the craft association (Zentralverband des Deutschen Handwerks) and the trade union federation (Deutscher Gewerkschaftsbund), are vivid examples for a structurally conservative point of view - circling around the dual apprenticeship system as the country's most valuable and functional VET sub-system and stressing the need to strengthen this pathway also in the future and under European conditions, and, above all, to protect it against the 'desires' of other educational sub-systems.

Nevertheless, stakeholders involved in the $\mathrm{DQR}$ working group are quite eager to use the new terminology based on the European paradigm, which appears to be so different from the VET system's cultural traditions: The latter undoubtedly have always included an understanding of VET which has a functional, i.e., occupational orientation, serving the labour market and helping companies involved in this kind of skill formation to reproduce their labour force on a high-quality level. Research in the UK has not become tired of stressing this competitive edge of Germany's apprenticeship 
system, and it is obvious that the skills issue in the UK policy debate has been underlying nearly all initiatives to reform the VET system during the 1970s, 1980s and 1990s (Prais 1981). At the same time, 'education' is an essential part of Germany's VET tradition: Both the legal framework supporting the apprenticeship system (Vocational Training Act 1969/2005) and the specific function of the vocational part-time school (Berufsschule). The following two quotations illustrate the differences between Germany and the UK in terms of their respective 'apprenticeship cultures' (Deissinger 2004):

Whereas in Germany the law is regarded as guaranteeing rights, in England legislation is viewed as restricting rights. Hence where the role, responsibilities and obligations of the participants including structures for cooperation in the dual system are set out in law there is very little comparable legislation in England. The law, then functions as a primary source of quality control in Germany. The system established in law provides continuity with the past building on established models and traditions. (Raggatt 1988, 176)

A striking difference from Germany is the absence of minimum training periods, such as a three-year programme for bakers. Similarly, apprentices need not take part-time technical education, unless they are MA participants functioning under an NTO framework that requires it - and even then no general education is required. Indeed, "off-the-job' training in a company training centre or with an external commercial provider is often enough to meet NTO requirements, despite concerns about its quality and relevance... The absence of process regulation reflects Britain's 'competence-based' approach to skill certification. What matters in principle for NVQ certification is demonstrated competence in the performance of work tasks, and that alone. Educational attainments should indeed form part of that assessment if they are needed for competence, but are otherwise to be discarded as superfluous... (Ryan 2001, 136f.)

The major concern of German stakeholders at the moment seems to be the preservation of this framework and the underlying 'vocational principle', commonly described as the 'organisational principle' within the German system of VET (Deissinger 1998), which stands for reliable and therefore portable vocational qualifications. Nehls $(2008,50)$, for example, points out that the alignment towards competence and employability skills should not mean that standardised learning processes (based on national training regulations) might be replaced by a combination of arbitrary learning objectives. Although the author maintains that the DQR should be constructed in a way to "enable all young people and adults to acquire recognised and high quality competences capable of long-term and marketable application on the labour market within the scope of lifelong learning' (50), the primary goals from the perspective of the social partners still refer to the established structures of the main segment of the German VET system, which is the dual apprenticeship system. Therefore, they seem to accept the EU terminology only in areas where these structures are not in a direct focus.

\section{The persistent boundaries within the German educational system}

With respect to this point of view, having in mind the contradiction of a competencebased modular approach and the 'vocational principle' (Deissinger and Hellwig $2005)$, the crucial attention given to the permeability issue does not, therefore, come out as a great surprise from the major stakeholders. Esser (2009) deploys the term 'removing pillars' (47), although in his perspective he pursues this concept with respect to the demarcation lines between VET and higher education - admittedly a 
highly relevant delineation within the German educational system - rather than to the borderlines responsible for the development of what has been labelled the "transition system' which undoubtedly is a product of an ill-functioning training market (Münk, Rützel, and Schmidt 2008). This 'transition' or 'measure system', which has significantly grown in the last fifteen years and which has become the object of considerable debate in both academic research and educational policy, also comprises, in a wider understanding of the term, full-time VET, which in contrast to the apprenticeship system, consists of various institutional patterns of vocational schooling with very different educational and didactical objectives (Deissinger, Smith, and Pickersgill 2006). Although the label 'opportunity enhancement system' euphemistically has been attached to this transition system, a closer examination of its structures reveals that there are at least two transitional thresholds which do not deserve to be associated with a real 'transition' or 'progression' perspective: (i) the first one being the transition from vocational training preparation and similar programmes, both in companies, schools and private training facilities, to 'regular' (i.e., formalised and therefore 'full') vocational training within the dual (apprenticeship) system; (ii) the second one being the transition from full-time VET into the dual system accompanied by the important issue of permeability and equivalence between the two major sub-systems of VET in Germany - especially when it comes to issues such as workplace orientation or practical training (Deissinger 2007).

In the following we will (firstly) focus, in a comparative perspective, on the differences between the way the German VET system faces and tackles these 'European' issues and Austria, which also has a similar apprenticeship tradition. Our suggestion is that a strong apprenticeship system makes it more difficult to adopt an European approach envisaging a more 'open' VET system, with links to other educational sub-systems including higher education. Two aspects will be picked up in more detail: (i) the issue of 'hybridity', both through the apprenticeship system and full-time VET, which stands for permeability between VET and higher education; and (ii) the issue of 'diversification', both in terms of qualifications and progression routes within the VET system. The first one means that a VET qualification can formally open up the gates of higher education; the second one means that a specific kind of VET qualification (including hybrid ones) may be obtained on different pathways within the VET system. In another step, this contribution focuses (secondly) on the French VET system, where both aspects, i.e., 'hybridity' and 'diversification' have become major features of educational reform, including a strong 'European' orientation.

\section{Hybridity in the VET system - a comparative view}

EQF and ECVET have been set up with the idea of improving transparency and comparability of qualifications and certificates. Besides, both European strategies aim at enhancing permeability and parity of esteem between general and vocational education (Busemeyer 2009, 5). One tool hereby is the implementation of hybrid qualifications (HQ) ${ }^{2}$ HQ still play a subordinate role within the German education system and there is also an obvious absence of this topic in the educational policy debate. This comes as a surprise as other European countries, including Switzerland and Austria, have successfully implemented and gained experience with hybrid pathways. A special focus will be given to France, where diversification, including hybridity, has become a major catalyst within the country's education system. 


\section{Germany}

In Germany, the concept of 'hybrid', or 'double qualifications' (Hybridqualifikationen, Doppelqualifikationen) is usually associated with the educational reform period of the 1960s and 1970s (Ganssert 1980, 184).

The acquisition of HQ refers to pathways in upper secondary education, including post-compulsory VET, whereby the clientele are students with an intermediate secondary school leaving certificate. Four different types of HQ, either in the apprenticeship system or in full-time VET, may be distinguished (Heine 2010, 12):

(1) The first type is a combination of a vocational qualification according to the Vocational Training Act (Berufsbildungsgesetz or BBiG) and a general school qualification leading to university (Abitur).

(2) The second type stands for the attainment of a vocational qualification according to the $\mathrm{BBiG}$ plus a polytechnic entrance qualification (PEQ) which gives no access to universities.

(3) Type 3 links a vocational qualification according to federal state law (e.g. an assistant qualification) with the acquisition of the Abitur.

(4) HQ according to type 4 are pathways where a vocational qualification according to federal state law and the PEQ can be acquired at the same time.

Due to the fact that the 16 German federal states are responsible for their respective school systems, the range of variation of HQ is distinctly heterogeneous in the national context.

HQ within the dual system (type 1 and type 2)

A special tension comes to mind once one looks at the apprenticeship system in Germany with its strong and nearly exclusive qualification purpose.

- Type 1: HQ according to type 1 are virtually non-existent. According to the database 'AusbildungPlus', there exist only three pilot projects (one in Thuringia, two in Berlin) offering the HQ 'dual apprenticeship training + Abitur' (BIBB 2009a).

- Type 2: Yet there are some possibilities where the trainees can acquire the PEQ in addition to a vocational certificate. The legal basis for such pathways has now been established in almost all federal states (Henke, Waldhausen, and Werner 2004, 253). Currently, 12 out of 16 federal states offer these kinds of HQ within the dual system based on an agreement of the Kultusministerkonferenz ${ }^{3}$ (KMK 2001). Some 8000 trainees in 176 vocational part-time schools have embarked on such a hybrid pathway (BIBB 2009b), although this is marginal (approx. 0.5 $\%$ ) within the total apprenticeship population (some 1.7 million). The trainees normally attend additional general education lessons apart from their regular apprenticeship (Waldhausen and Werner 2005, 42).

$H Q$ at vocational full-time schools (type 3 and type 4)

The dual system clearly outshines the system of full-time vocational schools due to its training function. In 2008/2009, out of about 2.8 million students in non-academic VET, some 1.7 million or $61 \%$ of the school-leaving population were undergoing an 
Table 1. German hybrid qualifications (type 3 and 4) indicating the corresponding number of graduates in selected federal states.

\begin{tabular}{lll}
\hline & $\begin{array}{l}\text { HQ type } 3 \text { at vocational } \\
\text { grammar schools }\end{array}$ & $\begin{array}{l}\text { HQ type 4 at vocational } \\
\text { colleges }\end{array}$ \\
\hline Baden-Württemberg & Non-existent & $\begin{array}{l}\text { Duration: } 2-3 \text { years } \\
\text { Graduates: } 8,293(2008)\end{array}$ \\
North Rhine-Westphalia & $\begin{array}{l}\text { Duration: } 3 \frac{1}{4}-4 \text { years } \\
\text { Graduates: } 819(2009)\end{array}$ & $\begin{array}{l}\text { Duration: } 3 \text { years } \\
\text { Graduates: } 4,665(2009)\end{array}$ \\
Thuringia & $\begin{array}{l}\text { Duration: } 31 / 2-4 \text { years } \\
\text { Graduates: } 171(2009)\end{array}$ & $\begin{array}{l}\text { Duration: } 21 / 2 \text { years } \\
\text { Graduates: } 325(2009)\end{array}$ \\
\hline
\end{tabular}

Sources: Statistisches Landesamt Baden-Württemberg (2009a); IT.NRW (2010a); IT.NRW (2010b); Thüringer Ministerium für Bildung, Wissenschaft und Kultur (2009).

apprenticeship in the dual system, while $39 \%$ were registered in full-time VET, including vocational preparation but also courses that lead to a comprehensive vocational qualification (Statistisches Bundesamt [Federal Statistical Office] 2010). Within full-time school based VET, some vocational grammar schools (Berufliche Gymnasien) offer an HQ according to type 3 while some vocational colleges (Höhere Berufsfachschulen or Berufskollegs) offer HQ according to type 4.

Type 3: the example of the vocational grammar schools in North Rhine-Westphalia

Vocational grammar schools in North Rhine-Westphalia optionally lead to a "vocational qualification according to federal state law + Abitur'. Students who would like to acquire the assistant qualification in addition to the Abitur can achieve this HQ within $3 \frac{1}{4}$ years. In 2009, some 6,200 grammar school graduates were awarded an Abitur at a vocational grammar school. Eight hundred and nineteen or $13 \%$ of these graduates attained an HQ (IT.NRW 2010b).

\section{Type 4: the example of the vocational college in Baden-Württemberg}

Since the mid-1970s, students in Baden-Württemberg have had the possibility to attend a vocational college (Berufskolleg) as an alternative to an apprenticeship training (Franz 2007, 6). The vocational college is a secondary, but post-compulsory institution, and as such is an alternative to the later years of the grammar school that academic students attend. It is open to students, normally aged between 16 and 18 , with an intermediate school leaving qualification. Students emerge from either the two-year vocational full-time school (Berufsfachschule), which takes graduates from the lower secondary schools normally aged 15 or 16 , the tenth year of lower secondary education (Werkrealschule), or from the two higher streams of the general education system (Gymnasium or Realschule).

This specific type of school now provides a PEQ as the 'regular' qualification. Under certain conditions, a vocational qualification according to the Baden-Württemberg school law (assistant qualification) can be obtained. Most students (approx. 33.8\%) attend a commercial vocational college (Statistisches Landesamt Baden-Württemberg [Statistical Office of Baden-Württemberg]2009b). According to an email message from Mrs. Jutta Demel of the Statistisches Landesamt Baden-Württemberg to the author on December 7,2009 , in $2008,8,293$ or $23 \%$ out of all graduates attained a HQ according 
to type 4. Currently, the function of the vocational college seems to be strongly entry into $\mathrm{HE}$ rather than delivering labour market qualifications - and research shows that this pathway is often chosen because of the PEQ (Ruf 2007, 120). Deissinger and Ruf (2006) found out that another important motivation of students seems to be the improvement of their position in the training market for a subsequent apprenticeship (e.g., banking or insurance) due to the insight that a college-based course fails to offer portable labour-market relevant occupational qualifications (Deissinger and Ruf 2006, 168f.). The dominance of and trust in the German apprenticeship system clearly is the corresponding side of this phenomenon.

Since a vocational qualification based on the Vocational Training Act (Deissinger 1996) receives nearly unrestricted acceptance from employers, HQ according to type 1 have the highest functional value, as the Abitur is valued more than a PEQ. However, HQ of such quality are practically non-existent in Germany. HQ type 4 certainly is the most widespread variant in all federal states. Therefore, it may be asserted that in Germany HQ only exist in a marginal field of the VET system.

\section{Austria}

Austria's VET system, as far as apprenticeships are concerned, has many similarities with Germany, due to many parallel historical developments going back to the Middle Ages. Also, Austria is a federal state although the central government has a major say in educational matters, including the regulation of schools involved in VET. The more 'holistic character' of the Austrian VET system may be an expression of this comparatively strong state regulation, but it is also the structure of the system itself which appears more homogeneous than in the German case. Generally, observers call it a 'three-column system' as two types of full-time VET (representing specific levels of

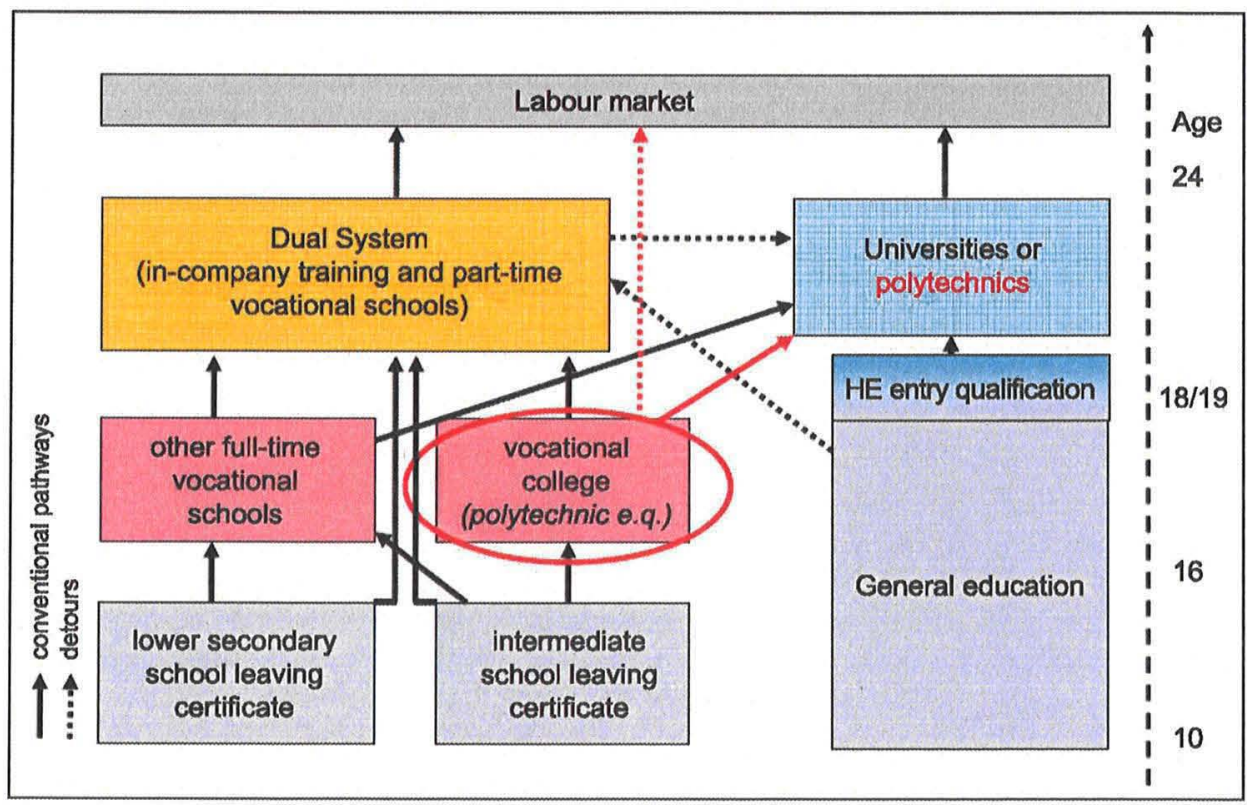

Figure 1. The vocational college within the German education system. 
educational achievement for a different clientele) stand in par with the dual system, which is not as highly rated both socially and economically as in Germany and is not seen as the most relevant pathway into skilled employment (Rauner 2008, 24).

From a German perspective, the analysis of the Austrian VET system and its educational pathways is valuable for many reasons. In contrast to the German education system, it is the attractiveness and success of the Austrian vocational full-time schools which clearly stand out (Aff 2006a). Austria demonstrates that offering a fully applicable HQ, even within a strongly differentiated education system, gives benefit to all educational pathways due to the concept of 'hybridity' (Schneeberger and Nowak 2000a, 61).

In 2007/2008, approx. $20 \%$ of all Austrian tenth year students attended a secondary academic school (AHS), which provides them with a general university entrance qualification (Matura). The striking feature within the Austrian education system, however, is that the majority of students in higher secondary education are located within vocational education. Two out of five students undergo vocational training within the dual system, whereas some $12 \%$ attend a vocational middle school (BMS) taking three to four years, and some $35 \%$ enter a VET college (BHS) which takes five years (BMUKK 2009, 18). Thus, in quantitative terms, initial vocational training within vocational full-time schools and apprenticeship training in the dual system can be regarded as equivalent. Aff speaks of a 'two-pillar model' on an equal footing (Aff 2006b, 126). The BMS are full-time schools which provide a basic general education and, at the same time, a fully-fledged occupational qualification (Archan and Mayr 2006,29 ). In contrast to Germany, Austrian vocational qualifications outside the dual system are portable, i.e., widely acknowledged and valued by companies (Neuber 1994, 41), which makes the BMS appear as a real and viable alternative to the apprenticeship system, even if the occupational areas are generally less specific than, e.g., in the craft sector, where apprenticeships even in Austria are still quite widely used as pathways of initial skill formation.

Compared to the vocational certificates awarded at a BMS or in apprenticeship training, a BHS vocational qualification is considered to be more demanding and of higher quality (Rothe 2008,100 ). Also, its 'polyvalent' character becomes more manifest as it combines the educational objective of an occupational qualification with the general entrance qualification for university (Matura). Both qualifications are gained simultaneously (Schneeberger and Nowak 2000b, 34; Maaz, Neumann, and Trautwein $2009,174)$. As a matter of fact, more than half of all university entrance qualifications in Austria have been obtained at the BHS (Fortmüller 2008, 1). ${ }^{4}$ According to Euler and Severing $(2006,117)$, approx. $50 \%$ of BHS graduates take up higher education, whereas the other half takes up employment in specific occupational areas. In contrast to Germany, the BHS concept is a 'simultaneous' model since German students can attain these qualifications only consecutively and usually after 15 or 16 years at school. ${ }^{5}$ Frommberger $(2007,147)$ maintains that this implies a clear disadvantage for German vocational training graduates on the 'European labour market'. The German educational expansion of the 1960s and 1970s led to a move towards grammar school education whereas the Austrian vocational full-time schools (in particular the BHS) experienced a strong expansion since the 1970s (Schneider 2001, 465; Lassnigg 1998, 109). ${ }^{6}$ Based on these findings, it can be stated that the BHS with its hybrid concept, both in curricular and functional terms, has a high reputation both with students and employers (Schneeberger 2002, 33). The BHS certainly is attractive since it offers entry into high-level occupational markets and the universities at the same time. In the 


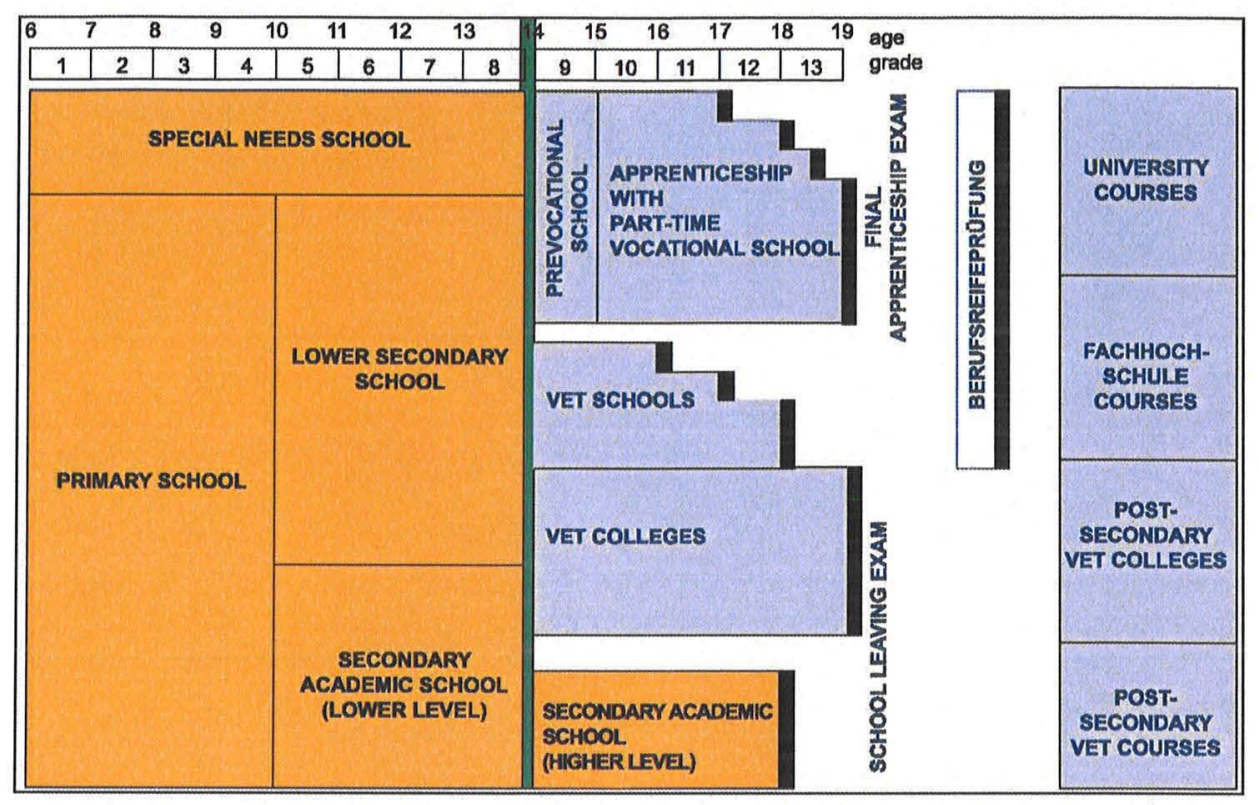

Figure 2. The Austrian education system at a glance.

Source: Tritscher-Archan $(2009,2)$.

case of a follow-up entry from the BHS to a polytechnic (Fachhochschule) there is even the option to get prior learning from the vocational school course accredited towards the academic course. How closely BHS and higher education seem to be interwoven can be seen in the fact that even titles commonly used in the tertiary system, such as 'Ingenieur' (normally a diploma qualification equivalent to a master), are awarded at the BHS in its technical variant (Archan and Mayr 2006, 55). In the same way, graduates of the commercial academies (Handelsakademien), as the businessoriented type of the BHS is called, receive occupation-based training as well as general education that enables them to attain the university entrance qualification for all subjects (Allgemeine Hochschulreife). Courses here also take longer than in general education (five years in comparison with the four-year courses at high schools).

The student numbers in recent decades indicate that both students and parents value these qualifications and it is in fact the five-year BHS course which has become increasingly attractive. As a matter of fact, the 'labour market integration share' of BMS and BHS rose from $21 \%$ to $57 \%$ between 1970 and 2005 (Hoppe 2005), and it is the BHS which is seen as the 'winner' of this shift away from both general higher secondary education and the apprenticeship system. With the introduction of Bachelor degrees in the wake of the 'Bologna process', however, the commercial academies could face increasing pressure, particularly in the more sophisticated occupational sectors.

Another interesting feature of the Austrian VET system is the so-called Berufsreifeprïfung (BRP), which was introduced in 1997, being an examination that enables graduates of the dual system and full-time VET schools to gain full access to HE (including access to university) (Klimmer 2008, 120). Nearly two thirds of BRP graduates come from the apprenticeship system, whereas some $30 \%$ graduate from a BMS. The acquisition of the BRP, which is a general qualification for university 
entrance, includes four exams: German, mathematics, one modern foreign language and the respective occupational area (Schneeberger and Nowak 2000a, 4). The fact that this examination (and the preparation courses) are now free of charge for all trainees certainly contributed to its growing attractiveness (BMUKK 2008). Based on the findings of Klimmer, Schlögl, and Neubauer $(2006,10)$, approx. $58 \%$ of BRP graduates continue their education immediately. Therefore, it may be stated that the Austrian system in fact provides progression routes into higher education through the VET sector in a formal and regular mode.

\section{The introduction of the French vocational baccalauréat as a stepping stone for diversification of learning pathways in the VET system}

VET in France traditionally and predominantly takes place in vocational full-time schools and it follows a 'meritocratic logic' which has characterised the education system since the French Revolution (Lutz 1986; Deissinger 1998, 184ff.). Since educational achievement and social status are linked to the level that can be attained in the education system rather than to the contents of the respective curriculum (Fourcade 2007), VET has traditionally played a marginal and rather inferior role, in particular in contrast with academic pathways and qualifications (Lattard 1999, 124).

For a long time, intensifying general and theoretical contents in VET courses was considered to be an instrument to increase the esteem of these pathways (Greinert 1999, 38 ), although employers articulated the need for competences that make employees useful and productive in the workplace. As a consequence, the VET system has lost more and more its functional character in relation to the labour market (Bouyx 2005, 31; Hörner 1996, 96; Lauterbach and Zettelmeier 2003, 6), which also means that job entrants have to cope with obstacles in the transition period between education and work, especially in times when the situation on the labour market is tense (Couppié and Mansuy 2004, 153; Gensbittel 1998).

During the 1970s and especially the 1980s, high youth unemployment in France forced the government to embark on reforms in the VET sector, realising that it was necessary to connect VET closer to the world of employment (Gendron 2005, 44-5; Tanguy 2005, 118-9). Out of this, two different (quite conflicting) political strategies emerged: the first one focused on increasing the general level of education and the second one on the promotion of workplace learning. Both approaches were inspired by VET systems in other countries: Japan which emphasised a higher level of general education (Gensbittel 1998, 20), and Germany whose economy has traditionally benefited from a well-performing dual system. The introduction of the baccalauréat professionnel (vocational baccalauréat), which comes close to a paradox within the French tradition of education, is one of these reform measures.

The French baccalauréat, being a very prestigious degree with a long-standing tradition, normally qualifies for university entrance (Vuillet and Siciliano 2003, 7; Eurydice 2000, 327; Kirsch 2006, 97-8), whereas the vocational pathways are seen as educational 'dead-end roads' with a low social value (Lattard 1999, 124). Therefore, the combination of baccalauréat' and professionnel' has provoked an ongoing discussion which also deals with the issue of how a qualification could serve two different sub-systems of education (Vuillet and Sicilano 2003, 9).

The French vocational baccalauréat, being on a higher level within the national education classification system than the already established VET qualifications, 'offers a second option, i.e., progression into higher education' (Deissinger 2009, 9). 


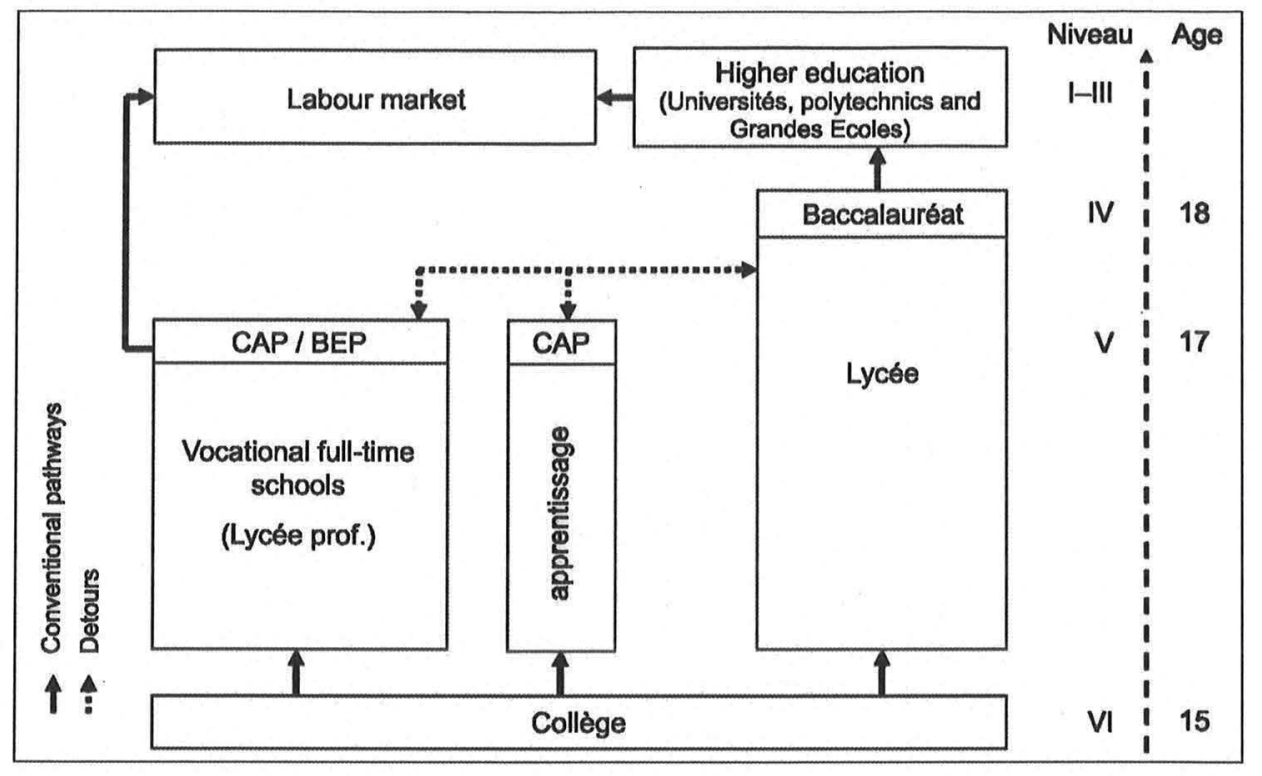

Figure 3. The French education system until 1985.

Therefore, it can be classified as a 'hybrid qualification' because it (formally) bridges the gap between VET and general and higher education respectively and works as a stepping stone within the French education system.

Against the conventional understanding of 'meritocratic logic', opening up a 'second option' through a specific kind of vocational certificate means that higher levels within the education system now can be achieved on a vocational pathway.

Another motivation for introducing the vocational baccalauréat has been to link vocational education more reliably with the labour market (Gendron 2005). Implementing two innovations within the French VET system, i.e., mandatory internships as elements of both the learning and the assessment process and the definition of vocational qualifications by learning outcomes are measures which have been taken to achieve this goal. These innovations originally were essential of the vocational baccalauréat philosophy, but have changed the whole VET system in the following years.

Vocational pathways leading to the vocational baccalauréat are now increasingly seen as alternating or dual pathways, due to the above-mentioned internships lasting at least four months (Hörner 1996, 96). This specific feature of the vocational baccalauréat challenges the implicit hierarchy in the French VET system which has always been in favour of school-based VET. With the expansion of school-based pathways in the 1950s, the apprenticeship system (apprentissage) almost disappeared, becoming the 'weakest element' within VET (Deissinger 2009, 9). Since 1971, the government has taken legal and political steps to promote the status of the apprenticeship system (Pollet 2007; Ott 2008) by stressing the importance of combining theoretical and practical learning and the need to comply with labour market needs (Ministère de l'Éducation nationale 2008). Introducing mandatory internships during the learning process, and their recognition in the assessment process, now makes workplaces accepted learning sites (Hörner 1996, 96; Bouyx 2005, 33; Kirsch 2006, 98). In 1987, two years 


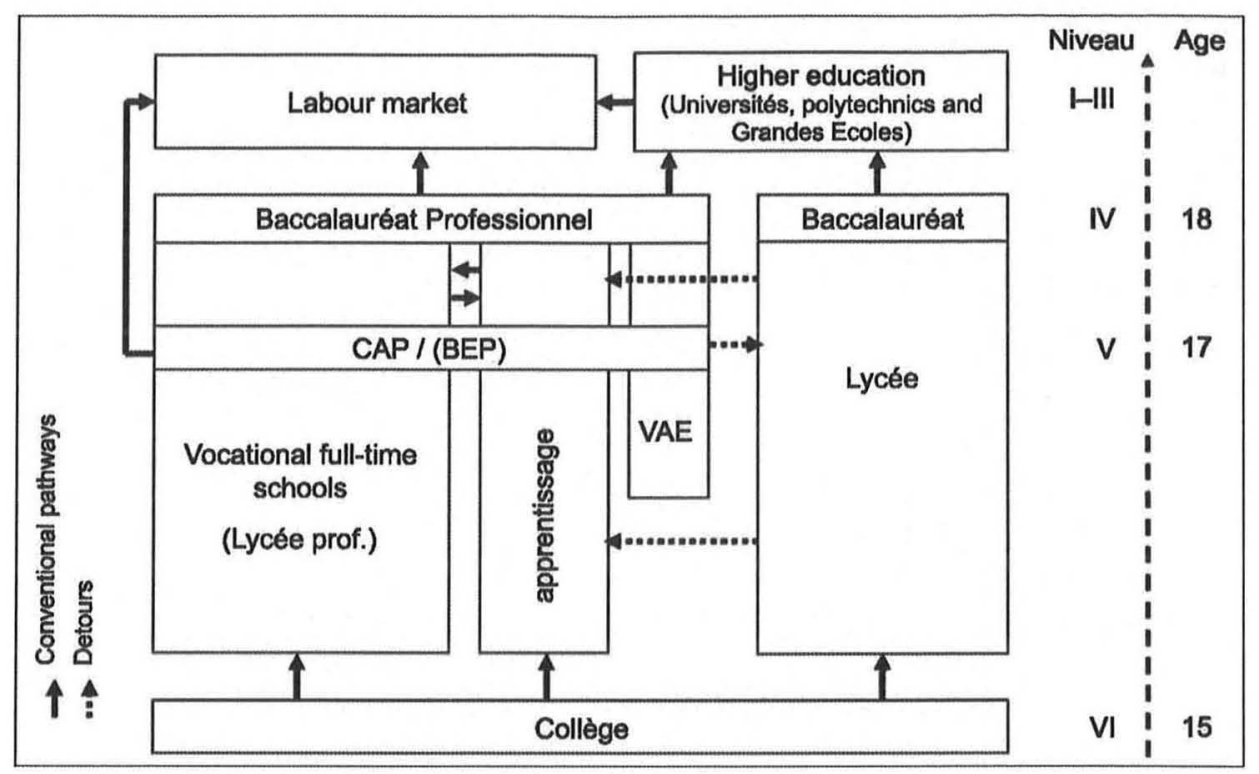

Figure 4. The French education system after 1985.

after the introduction of the vocational baccalauréat, all levels of the education classification system were opened up to apprenticeships (including graduate degrees in engineering) (Pollet 2007, 15). This means that all vocational diplomas, which were initially reserved for graduates from school-based education, have become attainable for apprentices. In 1993 and again in 2005, the French government stressed a target figure of 500,000 apprentices (Arrighi and Brochier 2005). Even if this number has not yet been achieved, some $29 \%$ of participants in initial VET at the secondary level are apprentices today (Ministère de l'Éducation nationale 2009, 152-3). Thus VET in full-time schools and VET in the apprenticeship system have become equivalent pathways leading to the same vocational qualifications. This fact can be seen as a result of the introduction of the vocational baccalauréat.

Another major move has been to place the various types of the vocational baccalauréat on an analysis of activities in corresponding occupations, which means a radical change in the process of curriculum development including the substantial participation of the social partners (Kirsch 2006, 98; Maillard 2003). This analysis is documented in the activity framework (référentiel d'activités professionnelles) and in the certification framework (référentiel de certification du domaine professionnel). These 'referentials' can be interpreted as an official definition of vocational qualifications or diplomas (Maillard 2003, 63).

The introduction of the reference frameworks can be interpreted as a 'shift from an 'input' to an 'output/outcomes' model' which has paved the way for the diversification of learning pathways (Brockmann et al. 2008, 232ff.). This means that contrary to the formerly close relationship between learning pathways and learning outcomes - where the certificate is considered as the logical completion of the learning process (Deissinger 2001, 201) - the emphasis today is on the independence of learning outcomes and learning pathways (OECD 2003, 7; Fourcade 2007, 48). A qualification 


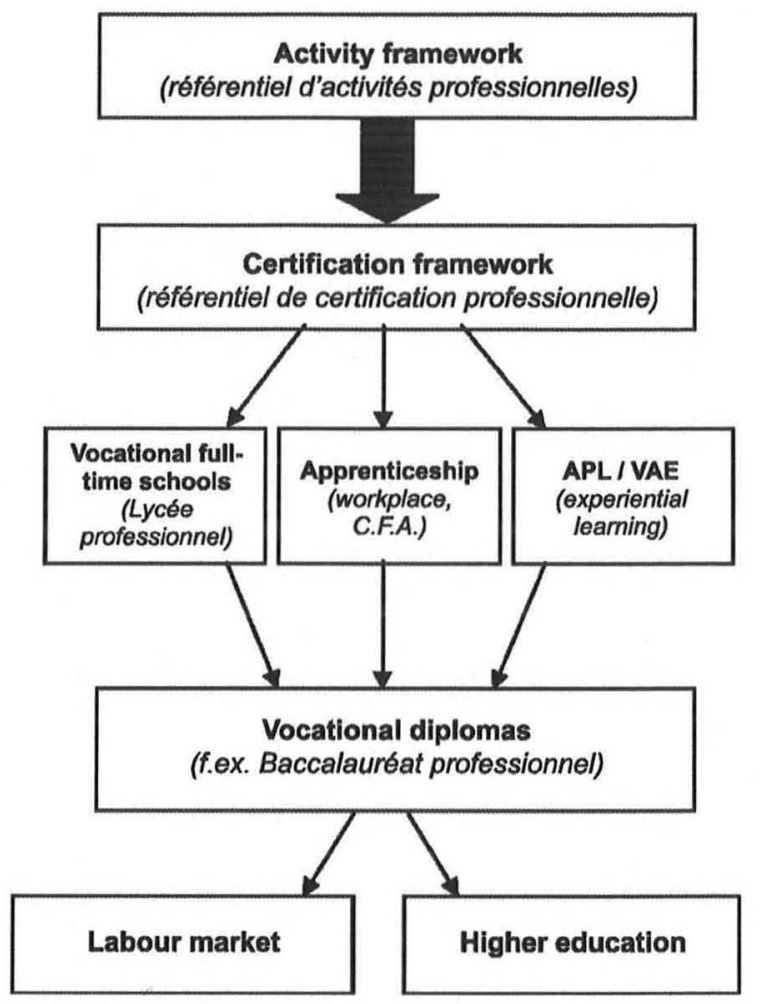

Figure 5. The role of the reference frameworks.

or diploma no longer sends out the message that a particular curriculum has been completed successfully, but now is supposed to attest an individual's 'competence', i.e., 'what individuals need to be able to do in relation to particular aspects of the occupation' (Brockmann et al. 2008, 233).

Since 2002, with the establishment of what is called validation des acquis d'expérience (VAE, a procedure for the accreditation of experiential or prior learning leading to vocational certificates in initial VET), no explicit learning processes are required at all (Maillard 2003, 64). Since VET in France has always been a highly formalised system, this change of perspective naturally provoked serious criticism. The major aspect of this criticism points to the missing balance between what generally describes occupations on the one side (this kind of description being often too abstract and outcomes being subject to broad interpretations), and the more concrete description of outcomes, which is seen as behaviouristic and cumulative, on the other side (Maillard 2003). Notwithstanding these theoretical issues, it becomes evident that the French VET system has proved to be highly innovative. What surprises is that the Anglo-Saxon understanding of 'competence' has become part of today's VET architecture. The fact that, in 2006, some $60 \%$ of 'participants' in the VAE procedure were able to obtain a full VET qualification (and even nearly $70 \%$ of those who went for a baccalauréat professionnel), illustrates that VET reform in France has taken major steps towards a more 'European', i.e., a more 'de-institutionalised' understanding of 'competence" ${ }^{7}$ (Ancel 2007). 


\section{Conclusion}

The challenge which most European countries face is coping with what may be called the 'CBET philosophy' underlying the EQF. Competence-based education and training (CBET) clearly is an Anglo-Saxon invention in the VET world. It is an approach to VET, in which skills, knowledge and attitudes are specified in order to define, steer and help to achieve competence standards on different levels of the respective national qualifications framework. Outcome orientation hereby places emphasis on new forms of assessment and 'competence' becomes detached from institutions, courses, curricula and formal examinations. These input features have traditionally been strong in most VET systems, both school-based and company-based ones, including apprenticeships. 'Recognition of prior learning' or 'accreditation of prior learning' (RPL/APL), mainly through work experience, is now seen as an essential tool to ensure the relevance and transferability of skills and knowledge as well as to lead people back into learning. These ideas have been picked up by the constructors of the EQF, although it has to be said that the focus of the EQF is not simply on a functionalist approach towards competence: firstly, because 'competence' is seen as a multi-dimensional term; secondly, because with the EQF competences are seen as learning outcomes in a universal understanding in the context of 'lifelong learning' (Hake 1999).

In the preceding chapters we have illustrated how Germany's VET system differs from both the Austrian and the French one in terms of its 'European' orientation and what problems spring off from a 'conservative' view of the apprenticeship system as the core of the VET sector. Our suggestion has been that a strong apprenticeship system makes it more difficult to adopt an European approach envisaging a more 'open' VET system, with links to other educational sub-systems including higher education. As we picked up the issues of 'hybridity' (in particular with respect to the Austrian VET system) and 'diversification' (in particular with respect to the French VET system) we have tried to show that both issues, both in political and practical terms, are obviously rather underrepresented in the German VET context. It is interesting that both Austria, as one of the traditional 'apprenticeship countries' in Europe, and France, as a typical 'school model', have implemented 'European tools' in their respective VET systems. Although the issue remains open whether this is really due to the European VET agenda, both countries hereby appear more 'prepared' than Germany. One common feature, however, catches the eye of VET research: all activities still circle around the issue of initial training, although the instruments are different: in the Austrian case, like in Germany, the institutional heritage of the national VET system plays a major role, whereas in France APL/RPL seems to have entered the VET system in a quite unique and 'non-traditional' manner. German VET policy might be well advised to look to its neighbouring countries not just for 'European' reasons, but also because the 'construction sites' in both the education and VET systems certainly would justify a more flexible and positive approach towards the European philosophy as both informal learning and VET in schools undoubtedly need to become a central issue of VET policy debate.

\section{Notes}

1. 'Hybridity' is the topic of an EU Leonardo Project entitled 'Hybrid Qualifications Increasing the value of VET in the context of Lifelong Learning', in which the authors participate. Partners in this project are: Alison Fuller (University of Southampton, UK), Josef Aff (Vienna University of Business and Economics, Austria) and Christian H. Jorgensen (University of Roskilde, Denmark). 
2. German literature differentiates between full and partial, integrative and additive as well as simultaneous and consecutive types of educational pathways which lead to HQ (Bojanowski 1996, 534; Dauenhauer and Kell 1990, 56f; Fingerle 1983, 198). As soon as it is possible for students to acquire both a school leaving certificate that entails access to higher education and a formal vocational qualification that allows students to enter into the labour market, we talk of full HQ (Dehnbostel 1996, 170). HQ described in this article are meant to be full HQ.

3. $\mathrm{KMK}=$ Standing Conference of the Ministers of Education and Cultural Affairs of the Länder in Germany.

4. In Germany, the Gymnasium (grammar school) is almost the exclusive way to university education.

5. Examples: (1) Acquisition of the university entrance qualification after 12 or 13 years at a grammar school and afterwards apprenticeship training (approx. 3 years). (2) Acquisition of the intermediate secondary school leaving certificate after 10 years, afterwards apprenticeship training (approx. 3 years) followed by two years in a so-called 'Berufsoberschule' (Stender 2006, 217).

6. Due to education policy in favour of vocational full-time schools, the number of BHS students quadrupled in the last 40 years although the total number of students decreased by a third (Specht 2009, 35).

7. 'Competence' (e.g., in the UK context) or 'competency' (e.g., in the Australian context) can be understood as 'the specification of knowledge and skill and the application of that knowledge and skill to the standard of performance expected in the workplace'. Consequently, CBET itself may be described as "training which is performance- and standardsbased and related to realistic workplace practices... It is focussed on what learners can do rather than on the courses they have done'. This definition (ANTA 1998, 10; Misko 1999, 3) places the focus of CBET on outcomes measured against standards rather than on courses based on institutional arrangements (classes in schools, e.g., or apprenticeships), where individual achievements are normally valued against others.

\section{References}

Aff, J. 2006a. Ein Blick über den Tellerrand. Die berufliche Erstausbildung in Österreich und Deutschland. Das duale System und das 'Zwei-Säulen-Model'. WissenPlus 1: 19-21.

Aff, J. 2006b. Berufliche Bildung in Vollzeitschulen - konjunkturabhängige Hebamme des dualen Systems oder eigenständige bildungspolitische Option? In Der europäische Berufsbildungsraum, ed. M. Eckert and A. Zöller, 125-38. Bielefeld: W. Bertelsmann.

Ancel, F. 2007. Du CAP au BTS: La validation des acquis de l'expérience poursuit son développement en 2006. Note d'information 7, no. 43: 1-4.

Archan, S., and T. Mayr. 2006. Berufsbildung in Österreich. Kurzbeschreibung. Luxemburg: Amt für Amtliche Veröffentlichungen der Europäischen Gemeinschaften.

Arrighi, J., and D. Brochier. 2005. 1995-2003, l'apprentissage aspiré par le haut. Céreq Bref 217: $1-4$

Australian National Training Authority (ANTA). 1998. Updated guidelines for training package developers: Australia's national training framework. Melbourne: ANTA.

Bojanowski, A. 1996. Modelle zur Doppelqualifikation. In Handbuch zur arbeitsorientierten Bildung, ed. H. Dedering, 533-59. München: Oldenbourg.

Bouyx, B. 2005. Les partenaires sociaux et les Commissions Professionnelles Consultatives (CPC). In Le partenariat social dans la formation professionnelle initiale en France. Actes des journées des 10-12 mars 2004, ed. E. Bentabet, J. Kirsch, and S. Stefani, 31-33. Marseille: Céreq.

Brockmann, M., L. Clarke, P. Méhaut, and C. Winch. 2008. Competence-based vocational education and training (VET): The cases of England and France in a European perspective. Vocations and Learning 1: 227-44.

Bundesinstitut für Berufsbildung (BIBB). 2009a. Projekt AusbildungPlus: Datenbank der Zusatzqualifikationen und Dualen Studiengänge. http://www.ausbildungplus.de/htmV/ 46.php.

Bundesinstitut für Berufsbildung (BIBB). 2009b. Projekt AusbildungPlus: Doppelqualifikation Berufsausbildung und Hochschulzugang. http://www.ausbildungplus.de/html/946.php. 
Bundesministerium für Unterricht, K. u. K. 2008. Berufsmatura: Lehre mit Reifeprüfung. Bessere Jobchancen durch Bildung. Perspektiven eröffnen - Potenziale nutzen. http:// www.bmukk.gv.at/schulen/bw/bm/berufsmatura.xml.

Bundesministerium für Unterricht, K. u. K. 2009. Zahlenspiegel 2008. Statistiken im Bereich Schule und Erwachsenenbildung in Österreich. http://www.bmukk.gv.at/medienpool/ 17604/zahlenspiegel_2008.pdf.

Busemeyer, M.R. 2009. Die Europäisierung der deutschen Berufsbildungspolitik. Sachzwang oder Interessenpolitik? Berlin: Friedrich-Ebert-Stiftung.

Couppié, T., and M. Mansuy, 2004. L'insertion professionnelle des débutants en Europe: Des situations contrastées. Economie et Statistique 378/9: 147-65.

Dauenhauer, E., and A. Kell. 1990. Modellversuche zur Doppelqualifikation/Integration. Bericht über eine Auswertung. Bonn: BLK.

Dehnbostel, P. 1996. Doppeltqualifizierende Bildungsgänge oder beruflicher Bildungsweg? In Doppelqualifikation und Integration beruflicher und allgemeiner Bildung, ed. R. Bremer, 167-80. Bielefeld: Bertelsmann.

Deissinger, T. 1996. Germany's vocational training act: Its function as an instrument of quality control within a tradition-based vocational training system. Oxford Review of Education 22: $317-36$.

Deissinger, T. 1998. Beruflichkeit als 'organisierendes Prinzip'der deutschen Berufsausbildung. Markt Schwaben: EUSL-Verl.-Ges.

Deissinger, T. 2001. Modularisierung und Beruflichkeit: Überlegungen zur Differenzierung eines vermeintlichen Gegensatzes. In Modernisierung der Berufsbildung in Europa, ed. H. Reinisch, R. Bader, and G.A. Straka, 195-204. Opladen: Leske + Budrich.

Deissinger, T. 2004. Apprenticeship cultures - a comparative view. In Apprenticeship: An historical re-invention for a post industrial world, proceedings of the conference held by the University Vocational Awards Council, ed. D. Hemsworth and S. Roodhouse, 43-58. London: UVAC.

Deissinger, T. 2007. "Making schools practical": Practice firms and their function in the full-time vocational school system in Germany. Education and Training 49, no. 5: 364-79.

Deissinger, T. 2009. The European qualifications framework and the European lifelong learning perspective: How European countries are preparing to cope with the new philosophy of VET. International Journal of Training Research 7, no. 1: 1-18.

Deissinger, T., and M. Ruf. 2006. Ubungsfirmen am kaufmännischen Berufskolleg in BadenWürttemberg. Praxisorientierte vollzeitschulische Berufsausbildung zwischen Anspruch und Wirklichkeit. Paderborn: EUSL.

Deissinger, T., and S. Hellwig. 2005. Structures and functions of competence-based education and training (CBET). A comparative perspective. Mannheim: InWEnt.

Deissinger, T., E. Smith, and R. Pickersgill. 2006. Models of full-time and part-time vocational training for school-leavers: A comparison between Germany and Australia. International Journal of Training Research 4, no. 1:30-50.

Delamare Le Deist, F., and J. Winterton. 2005. What is competence? Human Resource Development International 8, no. 1: 27-46.

Esser, F.H. 2009. Der DQR in der Entwicklung - Würdigung und Vorausschau. Berufsbildung in Wissenschaft und Praxis 38, no. 4: 45-49.

Euler, D., and E. Severing. 2006. Flexible Ausbildungswege in der Berufsbildung. Nürnberg/ St Gallen.

Eurydice. 2000. Vingt années de réformes dans l'enseignement supérieur en Europe: De 1980 à nos jours. France. Description nationale. Brussels: European Commission.

Fingerle, K. 1983. Bildungsgänge, doppeltqualifizierende. In Sekundarstufe II. Jugendbildung zwischen Schule und Beruf. Teil 2, ed. H. Blankertz, J. Derbolav, A. Kell and G. Kutscha, 198-201. Stuttgart: Klett-Cotta.

Fortmüller, R. 2008. Berufsausbildung und Studierfähigkeit. Zur Positionierung der Handelsakademien in einer geänderten Bildungsarchitektur. Berufs- und Wirtschaftspädagogik Online, Spezial 3 (Berufs- und Wirtschaftspädagogik in Österreich. Oder: Wer "macht" die berufliche Bildung in AT?: 1-11.

Fourcade, B. 2007. La politique des diplômes professionnels: Quelles relations à l'emploi. In Les diplômes de l'éducation nationale dans l'univers des certifications professionnelles. 
Nouvelles normes et nouveaux enjeux, ed. F. Maillard and J. Rose, 47-57. Céreq: Séminaire DGESCO.

Franz, C. 2007. Das Kaufmännische Berufskolleg in Baden-Württemberg. Untersuchungen zur gesellschaftlichen und didaktisch-curricularen Differenzierung einer komplexen Schulform. Dissertation, Universität Konstanz.

Frommberger, D. 2007. Berufsausbildung in Deutschland vor dem Hintergrund europäischer Entwicklungen. In Zukunft der dualen Berufsausbildung - Wettbewerb der Bildungsgänge, ed. H. Dietrich and E. Severing, 143-60. Bielefeld: Bertelsmann.

Ganssert, E. 1980. Integration von allgemeinem und beruflichem Lernen im Rahmen doppeltqualifizierender Bildungsgänge in Hessen. In Doppelqualifikation '78, BMBWWerkstattberichte 22, ed. Der Bundesminister für Bildung und Wissenschaft, 184-91. Bonn.

Gendron, B. 2005. Das berufsorientierte Abitur in Frankreich: Ein Raum, der Jugendlichen vielfältige Entwicklungsmöglichkeiten bietet. CEDEFOP - Berufsbildung 3, no. 36: 37-53.

Gensbittel, M. 1998. Le chômage des jeunes en France. Policy Options 19, no, 3: 19-22.

Greinert, W. 1994. The 'German system' of vocational education. History, organization, prospects. Baden-Baden: Nomos Verlagsgesellschaft.

Greinert, W. 1999. Berufsqualifizierung und dritte industrielle Revolution. Eine historischvergleichende Studie zur Entwicklung der klassischen Ausbildungssysteme. Baden-Baden: Nomos.

Hake, B.J. 1999. Lifelong learning policies in the European Union. Developments and issues. Compare 29, no. 1: 53-69.

Harris, R. 2001. Training reform in Australia. Implications of a shift from a supply to a demanddriven VET System. In Berufliche Bildung zwischen nationaler Tradition und globaler Entwicklung, ed. Th. Deissinger, 231-54. Baden-Baden: Nomos Verlagsgesellschaft.

Heine, R. 2010. Doppelqualifikationen - eine bildungspolitische Option für Deutschland im Zeichen der europäischen Berufsbildungspolitik? Diplomarbeit: Universität Konstanz.

Hellwig, S. 2006. Competency-based Training: Different perceptions in Australia and Germany. Australian Journal of Adult Learning 46, no. 1: 51-73

Henke, C., V. Waldhausen, and D. Werner. 2004. Verzahnung von Berufsbildung und Studium. GdWZ: Grundlagen der Weiterbildung 15, no. 6: 252-6.

Hoppe, M. 2005. Merkmale und Besonderheiten vollzeitschulischer Berufsausbildung in den Niederlanden, Österreich und Dänemark. Berufsbildung in Wissenschaft und Praxis 34, no. $4: 51-4$.

Hömer, W. 1996. Frankreich. In Bildungssysteme in Europa, ed. O. Anweiler, 83-107. Weinheim: Beltz Verlag.

Information und Technik Nordrhein-Westfalen (IT.NRW). 2010a. Berufliche Gymnasien in NRW. http://www.it.nrw.de/statistik/d/daten/eckdaten/r313kolleg_bg.html.

Information und Technik Nordrhein-Westfalen (IT.NRW). 2010b. Berufsfachschulen in NRW. http://www.it.nrw.de/statistik/d/daten/eckdaten/r313kolleg3.html.

Keating, J. 2008. Qualifications Systems and National Qualifications Frameworks. Paper presented at Monash University-ACER Centre for the Economics of Education and Training Annual Conference, October 31, in Melboume, Australia.

Kirsch, J. 2006. Zertifikate und Standards für die berufliche Bildung - geeignete Instrumente politischer Steuerung. Länderstudie Frankreich. In Standardisierung und Zertifizierung beruflicher Qualifikationen in Europa, ed. U. Clement, I. Le Mouillour, and M. Walter, 92-106. Bielefeld: Bertelsmann.

Klimmer, S. 2008. Die österreichische Berufsreifeprüfung - ein Instrument der Durchlässigkeit von der Lehre zur Hochschule. In Berufsausbildung im Umbruch. Ansätze zur Modernisierung des dualen Systems, ed. H. Loebe and E. Severing, 119-27. Bielefeld: Bertelsmann.

Klimmer, S., P. Schlögl, and B. Neubauer. 2006. Die Berufsreifeprüfung. Höherqualifizierung für den beruflichen Aufstieg oder für den Umstieg? Eine Status-quo-Erhebung. Wien: Bundesministerium für Bildung, Wissenschaft und Kultur.

Kultusministerkonferenz (KMK). 2001. Vereinbarung über den Erwerb der Fachhochschulreife in beruflichen Bildungsgängen. Beschluss der Kultusministerkonferenz vom 05.06.1998 i.d.F. vom 09.03.2001.

Lassnigg, L. 1998. Austria. In Pathways and participation in vocational and technical education and training, ed. OECD, 81-116. Paris: OECD. 
Lattard, A. 1999. Das Prinzip Alternanz. Zum Versuch der Modemisierung des bürokratischen Ausbildungsmodells. In Berufsqualifizierung und dritte industrielle Revolution. Eine historisch-vergleichende Studie zur Entwicklung der klassischen Ausbildungssysteme, ed. W. Greinert, 120-31. Baden-Baden: Nomos.

Lauterbach, U., and W. Zettelmeier. 2003. Länderstudie Frankreich. Länderstudie im Rahmen des BLK-Verbundprojektes 'Weiterbildungspass mit Zertifizierung informellen Lernens'. Frankfurt am Main: Deutsches Institut für Internationale Pädagogische Forschung.

Lutz, B. 1986. Bildung im Dilemma von Leistungselite und Chancengleichheit. Zeitschrift für Sozialisationsforschung und Erziehungssoziologie 6, no. 2: 193-212.

Maaz, K., M. Neumann, and U. Trautwein. 2009. Schulsysteme im deutschsprachigen Raum. In Handbuch Schule, ed. S. Blömeke, T. Bohl, L. Haag, G. Lang-Wojtasik, and W. Sacher, 171-79. Bad Heilbrunn: Verlag Julius Klinkhardt.

Maillard, F. 2003. Les référentiels des diplômes professionnels confrontés à leurs critiques: Une mise en valeur de leurs enjeux sociaux. Revue française de pédagogie, no. 145: 63-76.

Ministère de 1'Éducation nationale. 2008. Enseignement supérieur: Formations et diplômes: Formations en alternance. http://www.enseignementsup-recherche.gouv.fr/cid20247/lecontrat-en-alternance.html.

Ministère de l'Éducation nationale. 2009. Repères et références statistiques. Paris: MEN.

Misko, J. 1999. Competency-based training. Leabrook, SA: NCVER.

Münk, D., J. Rützel, and C. Schmidt, ed. 2008. Labyrinth Übergangssystem. Forschungserträge und Entwicklungsperspektiven der Benachteiligtenförderung zwischen Schule, Ausbildung, Arbeit und Beruf. Bonn: Pahl-Rugenstein Verlag.

Nehls, H. 2008. Noch kein Konsens bei der Konkretisierung eines Deutschen Qualifikationsrahmens. Berufsbildung in Wissenschaft und Praxis 37, no. 2: 48-51.

Neuber, R. 1994. Gleichwertigkeit von beruflicher und allgemeiner Bildung? Zur Struktur des oesterreichischen Bildungssystems. Wien: Institut für Bildungsforschung der Wirtschaft.

OECD. 2003. Le rôle des systèmes nationaux de certification pour promouvoir l'apprentissage tout au long de la vie. Rapport de base de la France. http://www.oecd.org/dataoecd/13/44/ 34327758.pdf.

Ott, M. 2008. Frankreichs Berufsbildung im Zeichen des Europäischen Qualifikationsrahmens. Eine kritische Analyse zu den aktuellen Struktur- und Entwicklungsfragen eines schulbasierten Berufsbildungssystems. Diplomarbeit, Universität Konstanz.

Pollet, P. 2007. Les évolutions suivies par l'apprentissage depuis 20 ans. Paper presented at Points de vue sur 1'apprentissage, November 28, in Paris, France.

Prais, S.J. 1981. Vocational qualifications of the labour force in Britain and Germany. National Institute Economic Review November, 98: 47-59.

Raggatt, P. 1988. Quality control in the dual system of West Germany. Oxford Review of Education 14, no. 2: 163-86.

Rauner, F. 2008. Steuerung der beruflichen Bildung im internationalen Vergleich. Eine Studie im Auftrag der Bertelsmann Stiftung. Gütersloh: Bertelsmann Stiftung.

Rothe, G. 2008. Berufliche Bildung in Deutschland. Das EU-Reformprogramm 'Lissabon 2000' als Herausforderung für den Ausbau neuer Wege beruflicher Qualifizierung im lebenslangen Lernen. Karlsruhe: Univ.-Verl. Karlsruhe.

Ruf, M. 2007. Der Ưbergang von der vollzeitschulischen Berufsausbildung in das Beschäftigungssystem als Herausforderung für die Berufsbildungsforschung. Theoretische und empirische Zugänge zum Problem der Akzeptanz vollzeitschulisch erworbener Berufsabschlüsse. Dissertation, Universität Konstanz.

Ryan, P. 2001. Apprenticeship in Britain - tradition and innovation. In Berufliche Bildung zwischen nationaler Tradition und globaler Entwicklung, ed. Th. Deissinger, 133-57. Baden-Baden: Nomos Verlagsgesellschaft.

Schneeberger, A. 2002. Bildung unter Modernisierungsdruck. Strukturwandel, veränderte Bildungsambitionen und Internationalisierung als Herausforderungen. Berufsbildung (CEDEFOP), no. 25: 73-88.

Schneeberger, A., and S. Nowak. 2000a. Doppelqualifizierung und berufliche Mobilität in Österreich. Abschlussbericht des Leonardo-Projekts, Zum Verhältnis von Doppelqualifikation und beruflicher Mobilität bei Fachkräften'. Wien: ibw.

Schneeberger, A., and S. Nowak. 2000b. Modernisierung dualer Berufsbildungssysteme. Probleme und Strategien in 7 europäischen Ländern. Wien: ibw. 
Schneider, W. 2001. Berufliche Erstausbildung zwischen Vollzeitschule und dualem System. Eine Analyse aus österreichischer Sicht. In Die Systeme beruflicher Qualifizierung Deutschlands, Österreichs und der Schweiz im Vergleich. Kompendium zur Ausund Weiterbildung unter Einschluß $\beta$ der Problematik Lebensbegleitendes Lernen, ed. G. Rothe, 465-72. Wien: öbv \& hpt.

Specht, W. 2009. Nationaler Bildungsbericht Österreich 2009. 1. Das Schulsystem im Spiegel von Daten und Indikatoren. Graz: Leykam.

Statistisches Bundesamt (Federal Statistical Office). 2010. Vocational schools. Pupils by types of schools. http://www.destatis.de/jetspeed/portal/cms/Sites/destatis/Internet/EN/Content/ Statistics/BildungForschungKultur/Schulen/Tabellen/Content75/BeruflicheSchulenSchulartSchueler,templateId=renderPrint.psml.

Statistisches Landesamt Baden-Württemberg (Statistical Office of Baden-Württemberg). 2009a. Email-correspondence with Mrs. Jutta Demel (Jutta.Demel@STALA.BWL.DE), December 7, 2009.

Statistisches Landesamt Baden-Württemberg (Statistical Office of Baden-Württemberg). 2009b. Statistische Berichte Baden-Württemberg. Berufliche Schulen in Baden-Württemberg im Schuljahr 2008/09. http://www.statistik.badenwuerttemberg. de/Veroeffentl/Statistische Berichte/3233_08001.pdf.

Stender, J. 2006. Berufsbildung in der Bundesrepublik Deutschland. Ein Lehrbuch. Teil 2. Reformansätze in der beruflichen Bildung. Stuttgart: Hirzel.

Tanguy, L. 2005. De l'éducation à la formation: quelles réformes? Éducation et Sociétés 2, no. 16: 99-122.

Thüringer Ministerium für Bildung, Wissenschaft und Kultur (Ministry for Education, Science and Culture of Thuringia). 2009. Email-correspondence with Mr. Andreas Thiele (Andreas.Thiele@tmbwk.thueringen.de),December 15, 2009.

Tritscher-Archan, S. 2009. Austrian VET system. http://www.ibw.at/images/ibw/pdf/bbs/ austrian_education_system.pdf.

Vuillet, C., and D. Siciliano. 2003. Qu'évalue-t-on avec les épreuves du baccalauréat professionnel? Rapport établi à la demande du Haut Conseil de l'évaluation de l'école. http:// lesrapports.ladocumentationfrancaise.fr/BRP/044000036/0000.pdf.

Waldhausen, V., and D. Werner. 2005. Innovative Ansätze in der Berufsausbildung. Höhere Durchlässigkeit und Flexibilität durch Zusatzqualifikationen und duale Studiengänge. Köln: Deutscher Instituts-Verlag.

Wolf, A. 1995. Competence-based assessment. Buckingham: Open University Press. 